\title{
Vida poética y vida ninfal. La importancia del arte en la elaboración temprana del concepto de «vida» agambeniano
}

\author{
«Poetic Life» and «Nymphal Life». The importance \\ of Art in the early Development of Agambenian \\ Concept of "Life"
}

\author{
Paula Fleisner \\ Universidad de Buenos Aires, Argentina \\ pfleisner@gmail.com
}

- Resumen · Este artículo estudia algunas de las figuras de la «vida» que se delinean en la estética de Giorgio Agamben. Lejos de tratarse de una prerrogativa exclusiva de su filosofía política posterior, también su temprana filosofía del arte contiene un pensamiento sobre lo "viviente» y una crítica al concepto moderno de «sujeto" que servirán de marco para aquella. Bajo esta hipótesis, se examina, primero, el proyecto de una "ciencia» intermediaria entre la crítica y la poesía, tal como se formula en Stanze. La parola e il fantasma nella cultura occidentale. Se evalúa, luego, la crítica al humanismo y a la construcción moderna de la subjetividad desarrollada a partir del análisis de la poesía moderna. Y, finalmente, se presenta una lectura de sus textos dedicados a Aby Warburg con el objetivo de dar cuenta de un original concepto de «vida histórica».

Palabras clave: vida, sujeto, poesía, Nachleben, espectáculo.

Abstract - This article examines some of the figures of «Life» that are outlined in Giorgio Agamben's Aesthetics. Far from being the exclusive prerogative of his later Political Philosophy, even his early Philosophy of Art contains a Thought about «Life» and a critique of the modern concept of «Subject» that will provide a framework for that. Under this hypothesis, we examine first the project of a intermediary «Science» between Criticism and Poetry, as formulated in Stanze. La Parola e il fantasma nella cultura occidentale. It's evaluated, secondly, both the critique of Humanism and the critique of modern construction of Subjectivity -developed from the analysis of Modern Poetry. Finally, we present a reading of his texts on Aby Warburg in order to account for an original concept of «Historic Life».

Keywords: Life, Subject, Poetry, Nachleben, Spectacle. 


\section{LA VIDA ANTES DE LA VIDA}

La problemática de la «vida» ha sido abordada de modo explícito por Giorgio Agamben a partir de la década del noventa, principalmente en sus obras dedicadas al diagnóstico político, volviéndose un concepto central de su filosofía. Así, «vida desnuda», «forma-de-vida», «vida potencial» o simplemente «lo viviente», son algunos de los modos en que este concepto ha sido pensado en sus libros más famosos, aquellos pertenecientes a la saga Homo sacer.

No obstante, la preocupación por la «vida», en cuanto concepto que podría venir en reemplazo del concepto moderno de "sujeto", ha estado presente desde el comienzo de su producción escrita que ocupada, como estuvo, en un análisis minucioso del arte y, más específicamente, de la poesía, ha moldeado su concepción posterior. Desde este marco general se ofrecerá aquí una lectura de dos ensayos de Stanze. La parola e il fantasma nella cultura occidentale, publicado originariamente en 1977, a partir de la cual se intentará demostrar una continuidad entre las preocupaciones estéticas tempranas y la preocupación política actual en un pensamiento, el del filósofo en cuestión, que se concibe a sí mismo como un lugar intermedio entre la filosofía y la poesía.

Stanze es una colección de cuatro ensayos que, desde su prefacio, se aleja de toda pretensión de «demostrar una hipótesis» o de presentar una argumentación «clara» y «distinta» en la búsqueda de un modelo de conocimiento que permita «entrar en relación con la irrealidad y con lo inapropiable en cuanto tal» (xVI). Surgido de «un inmenso trabajo de investigación en las bibliotecas de París, Londres y Roma, sobre textos de toda clase» (Sofri 33) y luego de un año en el Instituto Warburg, el libro mismo es, en cambio, un lugar, una stanza: el habitáculo en el que un coleccionista enamorado despoja, de su contexto y de su significado tradicional, a una serie de objetos construidos con palabras, libros y algunos otros hechos de imágenes. Al leerlo visitamos, en efecto, una especie de Wunderkammer personalísima organizada en función de una «ley del buen vecino» warburguiana ${ }^{1}$, por momentos temeraria y laberíntica.

No contamos con la ayuda de una Ariadna solícita que nos abra paso en el laberinto. Renunciemos, pues, a su cabal desciframiento. No obstante, una demora parcial en este libro abre dos cuestiones que abordaré en el presente trabajo: aunque sin un tratamiento explícito del problema de la "vida», Stanze ofrece, por un lado, una caracterización de la poesía moderna como el lugar en el que la figura de lo humano se disuelve hacia algo diferente que, si bien todavía no es «lo viviente»

Refiero aquí, implícitamente, el modo en que Agamben describe la Wunderkammer medieval en L'uomo senza contenuto, donde dice: «era una especie de microcosmos que reproducía, en su armonioso fárrago, el macrocosmos animal, vegetal y mineral» (47, la traducción es mía). La ley del buen vecino a partir de la cual se organiza la biblioteca de Warburg, dice Agamben, es aquella según la cual la solución del problema que presenta un libro está contenida no en ese libro, sino en el que está al lado. La biblioteca de Warburg era, de este modo, «una suerte de imagen laberíntica de sí mismo» («Aby Warburg e la scienza del nome»127, la traducción es mía). 
en general, tiene las características de lo «impersonal», algo más allá de la escisión entre sujeto y objeto que caracteriza al saber científico y filosófico tradicional. Por otro lado, al menos si se lo lee, como lo haremos, en relación con otros textos en los que Agamben sigue la herencia del pensamiento de Warburg, Stanze permite pensar la problemática de la «vida de las imágenes» o de su «supervivencia», es decir, una vida que, más allá del cuerpo biológico, sea una «vida puramente histórica».

Abordaré esta obra, entonces, con el objetivo de señalar estos dos aspectos, que, aunque olvidados entre sus comentadores, son algunos de los supuestos sobre los que se erigen las posteriores consideraciones agambenianas de la «vida». Comenzaré, de todos modos, señalando la interrelación especial entre arte, filosofía y política que parecería jugarse en este proyecto.

\section{FILOSOFÍA Y POESÍA, UN DEMORARSE ENTRE LA VERDAD Y LA TRANSMISIBILIDAD}

Los ensayos que componen Stanze plantean el problema de la posibilidad de reconciliación, descartada por Platón, entre poesía y filosofía. Reconciliación en la que otra relación, ni jerárquica ni fusional, entre el hablar y el saber, la palabra y la lengua, que no sea la que el proyecto metafísico del logos impuso, sea posible. Con ello, formula por primera vez una de las preguntas que se instalará con más fuerza en los próximos libros de Agamben y que moldeará todo su itinerario filosófico hasta hoy: ¿qué significa vivir como seres humanos?, ¿cómo se determina la vida en los animales así llamados hombres?

En la entrada «Gusto», escrita por esos años para la Enciclopedia Einaudi, Agamben se pregunta: «¿Es posible una reconciliación entre el estudio sistemático que conoce la verdad pero no la disfruta, y el gusto, que disfruta de la belleza sin ser capaz de dar razón de ella?» (1.020). Stanze es, precisamente, la búsqueda de ese lugar común en el que verdad y belleza, saber y goce, yacen uno al lado del otro en su indeterminación. Se ocupa, a lo largo de sus cuatro estudios relativamente independientes (sobre la melancolía, el fetichismo, el amor de las imágenes y la semiología), de contestar esta pregunta encontrando una zona intermedia, ni subjetiva ni objetiva, a través de una «crítica creativa», una especie de ciencia híbrida que no busca reencontrar un objeto propio, sino, tal vez, solo «asegurar las condiciones de su inaccesibilidad» (Agamben, Stanze XIII). La antigua enemistad entre poesía y filosofía, sancionada por Platón (Rep. 607 b-c) e interpretada en Occidente como una escisión entre la palabra que posee su objeto sin conocerlo y la palabra que lo conoce sin poseerlo, es uno de los nombres que en el pensamiento de Agamben recibe la operación de vivisección metafísica fundamental: en efecto, palabra / lengua, phoné / logos, placer / desinterés, o luego, animal / hombre, son algunos de los resultados de la máquina occidental de construir taxonomías a partir de una negación (mecanismo que algo más tarde será pensado por nuestro filósofo en términos de una exclusión-inclusiva). Aunque Agamben no lo 
mencione aquí de modo explícito, resulta fundamental para comprender su importancia el contexto en el cual Platón alude a esta palaiá diaphorá: se trata ni más ni menos que del final de una argumentación tendiente a la formulación de una polis justa. Así, el primer proyecto político occidental se funda sobre esta escisión de la palabra humana, poniendo en evidencia, por lo demás, una cohesión originaria, como dirá Agamben en Infanzia e Storia (1.978), entre poesía y política sobre cuya oclusión se construirá el edificio metafísico. Es por esto que Agamben puede decir en este libro, en sintonía con lo ya dicho en el prefacio de Stanze, que una crítica como la que él propone deberá «situarse en el lugar donde la fractura de la palabra que divide poesía y filosofía en la cultura occidental se vuelva una experiencia consciente y problemática» (Infanzia e Storia 148). Además, una tal crítica deberá asumir sus relaciones con la política y "plantearse sobre todo como antítesis de la ideología que se inserta en la disolución de esa cohesión» entre poesía y filosofía (148). No se trata, entonces, de preguntar si la poesía es relevante para la política, pregunta ociosa en el contexto del pensamiento agambeniano, sino de abordar el urgente problema de si la política «está todavía a la altura de su cohesión originaria con la poesía» (149).

Aunque subrepticiamente, la cuestión política aflora por esos años en su producción «estética» en su conexión con la decisión metafísica fundamental de hacer del hombre un viviente dividido, una cesura ontológica: ser hombre es estar siempre ya dividido, separado. La política será la continuación de la violencia metafísica por otros medios, como se pondrá de manifiesto mucho después en L'aperto, l'uomo e l'animale (2.002). Una política que asuma como propia la tarea de cortar incesantemente lo viviente para producir hombres, será un tipo de «biopolítica» ${ }^{2}$, de lo cual se ocupará, como dijimos, recién en la década del noventa. Pero aquí acaso se trate de pensar, in nuce, el reverso de dicha operación biopolítica: acaso se esté intentando pensar dónde ubicar, qué zona construir para una política «gestual», que se sitúe en un espacio de indiferencia entre la poesía y la vida ${ }^{3}$.

De este modo, si con Heidegger, a cuya memoria Stanze está dedicado, puede hablarse de un olvido en la historia de la metafísica occidental, ese olvido aquí es el de la escisión de la palabra humana. Verdad y belleza, pensamiento y lenguaje, lengua y palabra, crítica y creación han sido sistemáticamente separadas una de otras, y de lo que se trata es de hacerlas converger en una zona intermedia en la que podemos encontrar al melancólico, al fetichista, a las imágenes y a una cierta idea "esfingea» del lenguaje que asuma una «vinculación insignificable (synápsis) entre presencia y ausencia, significante y significado» (Agamben, Stanze 165).

Por ello, no implica este proyecto una reivindicación unilateral de la alegría poética frente a la seriedad filosófica, sino que intenta pensar más allá de la simple

2 Concepto que Agamben recoge de Foucault y que alude al modo en que la política toma a su cargo el cuidado y la administración de la vida biológica de los hombres. Sobre esta cuestión que excede los límites del presente artículo, cfr. el primero de los tomos de Homo Sacer I: Il potere sovrano e la nuda vita, de 1995.

3 Sobre el concepto de «política gestual» cfr. «Note sul gesto» y «Glosse in margine ai Commentari sulla società dello spettacolo». Volveré sobre esta cuestión más adelante. 
rivalidad entre ellas y sostenerse en la tensión entre ambas, en la «versura» originaria, ni poética ni prosaica, ni semiótica ni semántica, herencia poética en cuya oscilación el pensamiento deberá medirse. Esa es la ambigüedad de la palabra humana que se dirige simultáneamente hacia atrás (verso) y hacia adelante (prosa), que, antes de ser recortada, es originalmente prosimétrica, una mezcla entre verso y prosa: lugar perfecto para poetizar una vita nuova (Agamben, Idea della Prosa 21) ${ }^{4}$.

Se trata, en todo caso, según propone Agamben en «La parola e il sapere» (1980), de pensar otra figura de la lengua, una lengua de la que, como quería Dante, ya «no es posible una ciencia sino un amor» (159), un gay saber como el propuesto en la gramática de la lengua provenzal conocida como Las Leys d'Amors que fascinó tanto a Nietzsche: aquí el saber es una adoración de la lengua, un amor de las palabras (filo-logía $)^{5}$. Y es en esta stanza en la que la imbricación -que perfectamente se deja traducir como trampa (intreccio)-, metafísica de separar e implicar incesantemente el saber y el hablar, ha sido desactivada, donde filosofía y poesía se encuentran en una experiencia del lenguaje que «habla por sí mismo sin decir necesariamente nada específico» (Watkin 15).

\section{TRADICIÓN POÉTICA ANTIHUMANISTA, MÁS ALLÁ DEL SUJETO}

Luego de haber reconducido el temperamento melancólico a su componente erótico y amoroso, pero también potencial, en el primero de los ensayos, Agamben dedica el segundo a delinear ese tercer espacio entre sujeto y objeto en el fetiche, los juguetes y la obra de arte en la época de su mercantilización: todos ellos nos enfrentan a la paradoja de la satisfacción de la necesidad de un objeto inaferrable en su inaferrabilidad misma.

En los sucesivos capítulos de este ensayo Agamben presenta, primero, la idea freudiana de fetiche como algo infinitamente sustituible que remite siempre más allá de sí mismo, un objeto en el que se superpone un valor simbólico a su uso normal. Luego analiza el fenómeno descripto por Marx como «fetichismo de la mercancía», en el que lo que se superpone es el valor de cambio del objeto a su valor de uso.

$4 \quad$ Idea della posa es el libro más declaradamente poético de nuestro autor. Allí, Agamben analiza los últimos poemas de Caproni a partir del concepto de enjambement (encabalgamiento), efecto poético producido cuando la pausa del verso no coincide con la pausa morfosintáctica. Este efecto, nos dice, es el que evidencia el carácter "prosimétrico de todo discurso humano". Dante escribe su Vita Nuova bajo la forma de un prosímetro, siguiendo el modelo de De consolatione philosophiae de Boecio y de la razo de los trovadores stilnovistas.

Agamben interpreta en este artículo el inicio de De vulgari eloquentia, donde se opone una «vulgaris locutio» y una «lingua grammatica», en términos de la distinción saussureana entre la palabra y la lengua, como la oposición entre un hablar materno que es pura palabra (la lengua vulgar en tiempos de Dante) y un hablar que presupone necesariamente una lengua y una gramática. Alejándose de las interpretaciones tradicionales que ven en este pasaje una alternativa entre el programa de una lengua nacional y un arte poético, Agamben afirma que: «la singularidad del programa dantesco (como, en general, del programa trovador-stilnovístico) reside en que lo que está en cuestión es una relación entre saber y hablar, entre el hombre y el lenguaje, que es otro respecto de aquel sobre el cual el $\log o s$ ha construido su poder en la cultura occidental» (Agamben, "La parola e il sapere» 159 , la traducción es mía). 
Pero es en la consideración de Baudelaire y en su transformación de la obra de arte en mercancía absoluta (objeto cuyo valor reside en su inutilidad y su uso en su intangibilidad), donde Agamben encuentra el punto de inflexión a partir del cual se logra «la tarea más ambiciosa que ningún ser humano hubiese confiado nunca a una creación suya: la apropiación misma de una irrealidad» (Stanze 52).

Como ya lo había sugerido en L’uomo senza contenuto siguiendo los análisis de Benjamin, con Baudelaire el arte renuncia a su horizonte de pertenencia tradicional, deja de transmitir el mensaje cultural de una generación a la otra, se niega a sí mismo, bajo una forma de intercambio sacrificial anterior a toda «utilidad», para poder sobrevivir y salir del círculo del disfrute y la acumulación propio de la mercancía. El artista deberá entregarse en sacrificio para restituir a su esfera sagrada el objeto profanado por el uso servil. Pero esa restitución se realiza en un instante único en el que, en su «epifanía estética», el objeto a la vez recupera el sentido y se disuelve. El lema l'art pour l'art no significa otra cosa que la destrucción del arte por medio del arte mismo.

En esa nueva relación con las cosas, el principio de la pérdida debe ser llevado al extremo: el artista debe arrojarse a una cuidadosa labor de desposesión de sí, debe atravesar el muro que lo separa de las cosas y convertirse en una cosa. Sujeto y objeto dejan de ser realidades opuestas y enfrentadas. El sujeto sale de sí y se disuelve en la inmensidad objetiva, cosificando lo incosificable. Como el dandy que, en su imperturbabilidad, "ha abolido todo rastro de subjetividad de la propia persona» gracias a un ascético trabajo de exageración de lo irrelevante (62), el artista debe enajenarse, "convertirse en un cadáver viviente constantemente tendido hacia lo otro, una criatura esencialmente no humana y antihumana» (59).

Podríamos decir que en la muerte del «hombre» que hay en el artista, se da vida a la obra que se anula a su vez a sí misma. Lo otro a lo que tiende el poeta es un lado oscuro, demoníaco, es el reverso de la cultura, el «retroceso a la opacidad de la materia» del que ya se había ocupado Agamben en el primer artículo publicado de su carrera: "La $121^{\text {a }}$ giornata di Sodoma e Gomorra» ${ }^{6}$. Eso otro acaso sea la vida misma cuando ya no es el correlato objetivo que se entrega al sujeto en la relación de conocimiento, ese lugar que la poesía moderna ha inventado [sí, la vida es una invención, no un reducto metafísico más original que el poeta «descubre» en su autodestrucción] y transformado en su inquietante hogar, su oximorónico unheimliche Heim.

$\mathrm{Y}$ es que el centro de gravedad del arte, afirma Agamben casi al pasar, nunca ha estado en la esfera humana, por ello se equivocan los críticos reaccionarios como Ortega y Gasset cuando critican la «deshumanización» del arte moderno ${ }^{7}$. El arte, al

6 En este artículo, publicado en 1966, Agamben presenta un diagnóstico sobre el nihilismo de Occidente a través de una mirada sobre la concepción del teatro de Artaud. Como lo será en L’uomo senza contenuto (1970), su primer libro, el arte es aquí el lugar privilegiado para pensar el problema fundamental de la supervivencia de la cultura occidental. El teatro empujado a la radical otredad (a su sombra) que promueve Artaud, es un punto muerto en el que se reduce a la nada todo antagonismo entre materia y espíritu, entre idea y forma, entre concreto y abstracto.

7 Aunque Agamben no se refiera a ello, resulta curioso, en efecto, que en «La deshumanización del arte» Ortega analogue el fenómeno moderno de la deshumanización del arte con un cierto «asco 
menos en sus grandes épocas, nunca estuvo vinculado exclusivamente a lo "humano». Curioso. No se nos da aquí una explicación de esta afirmación, el interés de Agamben reside en señalar la especificidad de la poesía moderna como desenmascaramiento de la «ideología humanista» que, glorificándolo (podríamos decir aquí, retomando la reciente arqueología agambeniana de la gloria, «creándolo» ${ }^{8}$, transforma al hombre en un objeto. No obstante, podemos entender aquí que un arte que no pueda ser encerrado en el «humanismo» del discurso estético, está necesariamente situado en aquella morada en la que dioses, hombres y animales se demoran antes de ser producidos / recortados / capturados por los discursos ${ }^{9}$. Desenmascarar al humanismo, eso que Foucault llamó «la pequeña prostituta de todo el pensamiento, de toda la cultura, de toda la moral, de toda la política» (Foucault 616), es el proyecto que mancomuna a Apollinaire, Baudelaire, Rimbaud, Kleist, Lautréamont, Mallarmé, Benn, Montale y Celan, pero también a Matisse y a Klee: « ¡hay todavía figuras más allá de lo humano!», parecen gritar todos ellos.

Desarticular la subjetividad implica, para la poesía moderna, internarse en una «región inquietante», zona monstruosa, «en la que ya no hay hombres ni dioses» y en la que:

solo se alza incomprensiblemente sobre sí misma como un «ídolo» primitivo una presencia que es a la vez sagrada y miserable, fascinante y tremenda, una presencia que tiene al mismo tiempo la fija materialidad del cuerpo muerto y la fantomática inasibilidad del viviente (Agamben, Stanze 60, la traducción es mía).

Un lugar de epifanía y desaparición, una irrealidad aferrada en su carácter de inaferrable, fetiche y Grial, materia muerta, fantasma vivo, a cuya búsqueda se entrega el poeta hasta disolverse. Leído en consonancia con sus primeros artículos, este proceso de resacralización a través del sacrificio del poeta no debe confundirse con un retorno a lo sagrado primigenio, como una vuelta a la concepción del artista en tanto "ventrílocuo de dios», de la que Nietzsche supo burlarse (La genealogía de la moral 120). Se trata, en todo caso, del situarse de la poesía moderna en el umbral entre lo sagrado y lo profano, en esa esfera irreal, más acá y más allá de lo humano y de lo divino, mostrando y dislocando el funcionamiento de la máquina que los produce.

La problemática de la «desubjetivación» poética volverá a aparecer una y otra vez en los textos posteriores de Agamben. En Quel che resta di Auschwitz, por ejem-

a las formas vivas» y sospeche de la sensibilidad del «arte moderno» por el arte prehistórico y «el exotismo salvaje» (Ortega y Gasset 84). Al hacerlo, manifiesta su dependencia absoluta de la mirada estética tradicional que propone a su vez, siempre, una determinada lectura humanista de lo «vivo». Lo vivo es, desde esta perspectiva, lo humanamente determinado o determinable.

8 Me refiero, por supuesto, a la arqueología de la gloria emprendida en Il regno e la gloria, Per una genealogia teologica dell'economia e del governo, Homo sacer II, 2, especialmente en el Capítulo 8, 219-78.

9 En efecto, de este modo podría leerse la propia producción poética y narrativa de Agamben en sus primeras publicaciones. Me refiero tanto a su primera publicación, el cuento llamado «Decadenza» que publicó en una revista de ciencia ficción en 1964, cuyo protagonista es un pájaro que narra las desventuras de su especie, como a sus breves poemarios publicados entre 1967 y 1971, donde abundan toda clase de seres que desbordan y convergen unos sobre los otros. 
plo, en el seno de la construcción de su teoría del testigo, analizará la constitución paradójica de la subjetividad poética en una carta de Keats a John Woodhouse, que resume en cuatro tesis: 1) el yo poético no es un yo, no es idéntico a sí mismo; 2) el poeta es lo más impoético porque está siempre en lugar de otro cuerpo; 3) el enunciado "yo soy un poeta" no es un enunciado, sino una contradicción en los términos; y 4) finalmente, la experiencia poética es la experiencia vergonzosa de una desubjetivación. «En la tradición literaria occidental, el acto de la creación poética, y en efecto, todo acto de habla, implica algo así como una desubjetivación (los poetas llamaron a esta desubjetivación, Musa)» (Quel che resta di Auschwitz 105).

Que la literatura y la poesía modernas han minado desde adentro el proyecto metafísico moderno de una subjetividad fundacional, es una afirmación que Agamben repite a lo largo de toda su obra. «L'io, l'occhio, la voce» ofrece un análisis del proceso de deconstrucción del cogito cartesiano tanto en Monsieur Teste como en la obra poética de Paul Valéry. Allí se nos explica que es Valéry quien comprende, incluso antes de Benveniste, que «el yo es un puro límite insustancial», una realidad lingüística definible exclusivamente en el marco de una instancia del discurso. Al $J e$ no es lícito suponerle un Moi, pues es solo una máscara teatral impersonal. Y es especialmente en el "experimentum crucis» que es la poesía para Valéry, nos dice Agamben, donde se pone en evidencia el carácter radicalmente inhumano del yo poético. En la poesía habla siempre otro: «la Musa, Dios, Amor, Beatriz» («L’io, l'occhio, la voce»101).

A diferencia de Mallarmé, que aboliendo el yo llega a la instancia de la lengua misma, Valéry logra apuntar más allá del yo hacia la sensibilidad y el cuerpo. Pues el que habla en la poesía no es el yo, pero tampoco el lenguaje, sino «el Ser viviente y pensante» que impulsa la conciencia de sí a la captura de la propia sensibilidad sobre la cuerda de la voz (102). Encuentra Agamben en El diálogo del árbol la idea de un lenguaje que brota de la voz, donde la voz es justamente «el elemento que permite la unión entre conciencia y sensación» al que el yo y el cuerpo acceden a través de lo inefable que aquí se presenta como «la fuente de las lágrimas». Citemos in extenso el pasaje que Agamben retoma:

[...] Y es allí, en el seno de las tinieblas en las cuales se funden y se confunden lo que es de nuestra especie, y lo que es de nuestra materia viva, y lo que es de nuestro recuerdos, y de nuestras fuerzas y debilidades escondidas, y lo que es, en fin, el sentimiento informe de no haber sido siempre y de deber cesar de ser, que se encuentra eso que he llamado la fuente de las lágrimas: LO INEFABLE. Porque, nuestras lágrimas a mi entender, son la expresión de nuestra impotencia de expresar, es decir, de deshacernos por la palabra de la opresión de eso que somos... (Valéry 45).

Así como en Il linguaggio e la morte (1982), Agamben describe el proceso filosófico a través del cual la voz se transforma en la Voz, «fundamento negativo sobre el que descansa toda la onto-lógica, la negatividad originaria» (50), en «L'io, l'occhio, la voce» culmina señalando que, como antes Artaud, también Valéry arriba 
a un impasse, a la experiencia de un límite, de un naufragio en lo indecible, pues ninguna voz puede decir la disolución del sujeto: disolución que solo se produce con la imposible muerte de esa ficción teatral que es el sujeto. Sin embargo, acaso podamos retener de esta cita de Valéry esa idea de tiniebla confusa en la que cohabitan sin articulación alguna los elementos fisiológicos y sentimentales, materiales y espirituales, que son forzados en el lenguaje a reunirse de determinada manera, a construir el artefacto que somos, la opresión que somos. Esta tiniebla tal vez sea aquella precariedad de la existencia común a todo lo viviente que el pájaro de «Decadenza» ponía en evidencia en su relato ${ }^{10}$. Precisamente porque el sujeto es lo que no puede morir, está muerto desde el comienzo, no comparte con todo lo viviente esa existencia condicional, la posibilidad perpetua de revocación. De esa tiniebla -entre nosotros, seres recortados y pegados a una «esencia»-, solo el llanto puede dar cuenta; el llanto como un discurso físico defendido por el poeta Titiro, frente al «intelectual» Lucrecio ${ }^{11}$; el llanto como un encuentro no subordinante entre conciencia y sensación que descalabra la certeza del sujeto pensante.

Más adelante, en la obra sucesiva, el sujeto será pensado por Agamben como un «resultado», como el producto de una permanente tarea de subjetivación / desubjetivación siempre en movimiento sobre lo viviente. Hasta aquí, nuestro interés principal ha sido el de señalar la especificidad de la poesía moderna como discurso antihumanista. La poesía moderna, tal como es pensada por Agamben, es un discurso que desenmascara, en el mismo momento de su creación, la falsa conciencia que ha inventado al hombre, y que ha buscado su esencia y su liberación en el mismo gesto de su sujeción ${ }^{12}$.

10 Dicho brevemente, este cuento narra la historia de una comunidad de pájaros que retorna cada día a la misma playa para incubar sus huevos, que han dejado de abrirse desde hace ya mucho tiempo. El narrador es un pájaro perteneciente a una generación intermedia, la «penúltima antes de que los huevos dejaran de abrirse» (Agamben, «Decadenza» 28), entre los viejos jefes, que conocen el sentido del ritual y pasan sus días inventando estrategias para lograr una apertura que no llega, y los jóvenes, que ven en la incubación algo morboso e insano, sospechan que nada hay dentro de los huevos y complotan para romperlos. Esta juvenil escritura literaria deja esbozadas algunas temáticas que serán centrales no sólo en los poemas y artículos de los años inmediatamente posteriores sino también en la producción teórica sucesiva.

11 Este diálogo fue leído en el Instituto de Francia en octubre de 1943, y en esa ocasión Valéry afirmó: «Los discursos más o menos poéticos consagrados a la gloria de un Árbol, se intercambiaron entre un Titiro y un Lucrecio, cuyos nombres he tomado sin consultarlos» (Valéry 19). El pasaje que cita Agamben, que aquí reproduzco, es un parlamento de Titiro.

12 Es por ello que, a pesar de su fecundo análisis de Stanze como obra a partir de la cual puede comenzar a pensarse un sujeto potencial, me alejo del punto de vista de Bartoloni, quien lee en este texto un intento de pensar «una nueva manera de hablar del yo y del lenguaje» (9, la traducción es mía). Mi lectura, por el contrario, ha ensayado en Stanze (e incluso en las obras que lo anteceden) una interpretación del pensamiento agambeniano donde el «yo» es asumido como una construcción y se disuelve como resto, dando lugar a una concepción más general de «lo viviente» que se manifiesta en los escritos posteriores. 


\title{
IV. VIDA Y SOBRE-VIDA DE LAS IMÁGENES
}

\author{
Noi siamo abituati ad attribuire vita soltanto al corpo biologico. \\ Ninfale è, invece, una vita puramente storica.
}

Agamben

\section{La influencia warburguiana}

Como dijimos, Stanze surge luego del encuentro definitivo de Agamben con el pensamiento de Aby Warburg. Ya asiduo lector de Heidegger y de Benjamin, nuestro autor se encuentra en Londres con un modo de estudiar las imágenes que trasciende el intento de comprender su «significación» y busca comprender su "vida». Como señala Didi-Huberman, el arte es para Warburg «una cuestión vital», no una mera cuestión de gusto (279). Tras los pasos de Burckhardt y de Nietzsche, Warburg reivindica en su lectura del arte del Renacimiento una «vida póstuma», a la vez natural (sensorial, emotiva) e histórica (cultural), de las imágenes, un pasaje de la vida al arte al modo de aquella promesa de felicidad que fue el arte para el Pigmalión de Nietzsche (Nietzsche, La genealogía de la moral 121) o para Frenhofer antes de su encuentro con Poussin (Balzac 59) ${ }^{13}$.

Si bien Stanze no presenta un tratamiento detallado del problema del Nachleben, Agamben se había detenido antes en esta cuestión, en el artículo de 1975 «Aby Warburg e la scienza senza nome», y volverá sobre ella en 2004 en un artículo publicado en un número de Aut Aut dedicado enteramente al pensamiento de Warburg ${ }^{14}$. Analizaré a continuación los tres textos en conjunto bajo la hipótesis de que una cierta lectura de esta cuestión, aunque no completamente explícita, permitiría a Agamben pensar la «vida» de un modo «estético», más allá de la «metafísica de la vida» que desemboca en el nihilismo de la estética moderna, de la que se ocupó en L'uomo senza contenuto ${ }^{15}$.

En efecto, leída a partir de algunas interpretaciones recientes, la idea warburguiana de supervivencia de las imágenes podría implicar una concepción de la «vida» como «fuerza» o "potencia» impersonal directamente relacionada con el «hacer»

13 De ambas cuestiones, de la oposición nietzscheana entre la concepción de Stendhal del arte como promesa de felicidad y de la concepción kantiana del arte como desinterés, por un lado, y de «La obra de arte desconocida» de Balzac, por el otro, se ocupó Agamben en L’uomo senza contenuto, Cap. 1 y 2, respectivamente.

14 «Aby Warburg e la scienza senza nome» se publica originariamente en Prospettiva settanta en 1975, en 1984 se publica nuevamente con una apostilla en la revista Aut Aut y, finalmente, en 2005 es compilado en La potenza del pensiero (cito aquí esa edición, 123-46). "Nymphae», el artículo del 2004, se publica en un número especial de Aut Aut ( $\left.\mathrm{N}^{\circ} 321-22\right)$, titulado: "Aby Warburg. La dialettica dell'immagine» (cito esta edición), y vuelve a publicarse separadamente en forma de pequeño libro con el nombre Ninfe en 2007 en la editorial Bolatti Boringhieri.

15 No puedo aquí recomponer el diagnóstico del primer libro de Agamben contra al cual Stanze se presenta. No obstante, para una genealogía de la relación entre una «metafísica de la voluntad pura y autónoma» y la «metafísica de la vida y de la creatividad» cfr. Tarizzio, X-XviI y Agamben, Stanze, 109. 
del arte, entendido como producción de formas sensibles. De este modo, la «vida de las imágenes» sería una especie de producto híbrido entre naturaleza y cultura, que nos ofrece una posible relación entre arte y vida no sostenida en una metafísica del impulso vital.

En el prefacio de Stanze, Agamben inserta su investigación en el marco del diagnóstico warburguiano sobre la esquizofrenia del hombre occidental: «En nuestra cultura, el conocimiento [...] está escindido en un polo extático-inspirado y en un polo racional-consciente, sin que ninguno de los dos logre nunca reducir íntegramente al otro» (XIV-XV). Pero, además, Agamben parece comprender su búsqueda de una «ciencia sin objeto» al modo de la «ciencia sin nombre» de Warburg, esa disciplina interdisciplinaria ubicada en el umbral de otras, no identificable con ninguna de ellas y tutelada por un «buen dios que se esconde en los detalles» (Agamben, «Aby Warburg e la scienza senza nome» 125). Es decir, con Warburg se hace posible concebir una investigación en el entrecruce de la abstracción filosófica y el detalle filológico en la que la descripción de un fenómeno nimio (la imposible traducción al italiano de la palabra Stimmung, la implicancia de la barra [/] que separa significado de significante en la semiología saussuriana, o el uso de determinados signos de puntuación, por ejemplo) se abra a las cuestiones ontológicas fundamentales ${ }^{16}$.

A su vez, en el tercer ensayo de esta obra, «La parola e il fantasma», Agamben enmarca, explícitamente, su "genealogía de la fantasmología medieval» en la concepción warburguiana de la cultura como un proceso de transmisión de Nachleben. En su restitución del "amor heroico" al mundo de la patología médica y a la demonología neoplatónica, Agamben descubre la formación, intrínseca al desarrollo cultural de Occidente, de dos aspectos mutuamente excluyentes que conviven en una misma figura del amor. Eros está "polarizado en la tensión lacerante de dos extremos de signos opuestos», pues el amor es para los poetas del siglo XII, una enfermedad mortal de la imaginación que, lejos de intentar curarse, debe atravesarse hasta el fondo "porque al lado de un riesgo letal encierra una extrema posibilidad de salvación» (Agamben, Stanze 131). Su reconstrucción del "amor a la imagen», que va desde la elaboración antigua de la teoría del fantasma (Platón y Aristóteles) hasta la literatura del siglo XIII, pasando Avicena y Averroes, o el De insomniis de Sinesio, y el stilnovismo, es una confirmación de lo que Warburg demostró para la historia de las imágenes, es decir, de que la cultura occidental se desarrolla y transforma a través de un proceso de polarización de la tradición cultural recibida. «Las creaciones y revoluciones operan polarizando los datos proporcionados por la tradición hasta su total inversión semántica» (Agamben, Stanze 131).

Agamben explica este proceso de polarización, presente hasta hoy por ejemplo en la ambigüedad de la concepción occidental de la felicidad, a partir de la "pre-

16 Los ejemplos que cito entre paréntesis son investigaciones de Agamben realizadas en «Vocazione e voce» (1980), «Pardes» (1990) y "L'immanenza assoluta» (1996), artículos compilados en La potenza del pensiero, y en el cuarto ensayo de Stanze, "L’immagine perversa. La semiologia dal punto di vista della Sfinge» (157-90). Para un análisis de esta cuestión cfr. De la Durantaye, 66. 
existencia, en el seno de la herencia transmitida por la tradición, de una tensión potencial, que precisamente se reactualiza y se polariza en el encuentro con la nueva época»; y agrega entre paréntesis:

(Aby Warburg hablaba, a propósito de los símbolos culturales como de «dinamogramas» o condensadores eléctricos que transmiten una carga energética en toda su tensión, pero sin caracterizarla semánticamente de modo positivo o negativo) (137-8).

Se trata aquí de pensar el Nachleben de una fórmula patética (Pathosformel) expresada en palabras, la fórmula del "amor por la imagen", que se presenta como la cristalización de experiencias polares: la de la contemplación del fantasma interior (herencia de la teoría antigua que hace del fantasma el «centro de una constelación psíquica», condición necesaria de la inteligencia, del sueño, de la adivinación, del carácter semántico del lenguaje, de la memoria y de la sensación) y la de la concupiscencia (heredada por una igualmente antigua teoría del pneuma como principio vivificador del universo y del hombre). Con Sinesio, afirma Agamben, se produce una asimilación entre pneuma y fantasma (entre el soplo cálido y la imagen interior) en la idea de «espíritu fantástico", que se presenta como el perfecto intermedio entre irracional y racional, corpóreo e incorpóreo; y es a partir de aquí que puede hablarse de una pneumo-fantasmología: un mismo soplo anima al universo, circula en las arterias, fecunda al esperma y forma los fantasmas de las cosas que vemos, imaginamos, soñamos y amamos (Stanze 53). Esta asimilación estará a la base de la lírica stilnovista que presenta una experiencia única del amor que es a la vez contemplación y concupiscencia, movimiento espiritual y proceso fantasmático, confusión de los confines entre el deseo y su objeto.

La Pathosformel, cuya genealogía se explora aquí, no es extraída de la tradición iconográfica, aunque se rastrea al menos tangencialmente su dimensión imaginal ${ }^{17}$. No obstante, acaso sea posible extender la idea de «fórmula del pathos» más allá de los análisis warburguianos hacia la composición poética, como lo hace por ejemplo el propio Agamben en «Nimphae», donde compara esta idea con la de composición formular de los poemas homéricos según los análisis que realizara por los mismos años que Warburg, Milman Parry ${ }^{18}$. Ambos conceptos comparten un carácter híbrido entre creación y performance, entre materia y forma, entre primera vez y repetición, señala Agamben ( «Nimphae» 55-6). Por lo demás, el propio Warburg, en «Durero y la antigüedad italiana», menciona una obra de teatro como prueba de la «experiencia efectiva revivida pasional e inteligentemente en el espíritu» que implica la Pathos-

17 Agamben refiere, por ejemplo, la precisión con la que las ilustraciones del Roman de la rose dan cuenta de las implicancias eróticas "perversas»-lujuriosas- y «ceremoniales»-religiosas- del episodio de Pigmalión o del episodio del final del poema, cfr. Agamben, Stanze, 76-7.

18 Agamben no refiere aquí una obra particular de Parry. No obstante, su teoría se evidencia, por ejemplo, en un artículo publicado originariamente en 1930, donde se lee la siguiente afirmación: «la fórmula en los poemas homéricos puede ser definida como un grupo de palabras que es regularmente usada bajo las mismas condiciones métricas para expresar una idea esencial dada» (Parry 272). 
formel de la «muerte de Orfeo» en un dibujo de Durero y en el grabado sobre cobre anónimo que le sirvió de modelo. Es decir, en el mismo momento de su formulación inicial, este concepto es pensado también dentro de la esfera literaria, pues la obra de teatro de Poliziano, Orfeo, que expresa el sufrimiento de Orfeo «con los mismos ritmos que Ovidio», es una representación más de esa «voz genuinamente antigua» que sobrevive en el arte del siglo xv. Voz que no puede ser reducida, como veremos, al mero tema primario de una imagen ${ }^{19}$. Finalmente, ya en su tesis de 1893 había logrado identificar a la "ninfa» como nuevo tipo iconográfico en Botticelli, gracias a un análisis de fuentes literarias que incluyen a Homero, Ovidio y a Poliziano ${ }^{20}$. Por estos motivos, no sería insensato entender el locus del «amor por la imagen» en términos de la condensación de emociones primordiales que constituye las Pathosformeln warburguianas.

En este ensayo de Stanze, Agamben no ofrece definiciones de los términos de Warburg a partir de los cuales construye su interpretación de la experiencia de amor stilnovista, pues ya lo había hecho en parte en «Aby Warburg e la scienza senza nome». Allí se presentaba el concepto de Pathosformel como un intento de ir más allá de la estética formalista. Este concepto implica una necesaria indistinción entre forma y contenido porque «designa una indisoluble imbricación de una carga emotiva y de una fórmula iconográfica» (Agamben, "Aby Warburg e la scienza senza nome» 125). Las fórmulas del pathos son el repertorio gestual de las cristalizaciones de las experiencias polares producidas por una serie de huellas de estímulos externos impresos en la psique (que Warburg, con Semon, llama «engramas»), huellas que producen respuestas automatizadas ante la aparición de esos mismos estímulos. Las Pathosformeln son, entonces, los mecanismos sensibles a través de los cuales las formas artísticas objetivan los engramas y suscitan el recuerdo de experiencias emotivas primitivas (g. Burucúa 28-9). En las obras de arte este lenguaje gestual patético, estereotipado y repetitivo, es el tema imaginal con el que se mide el artista "para dar expresión a la vida en movimiento», dirá Agamben en «Nimphae» (55).

Según señala E. Wind, «[u]na de las convicciones básicas de Warburg era que cualquier intento de separar la imagen de la religión o de la poesía, del culto o del drama, es como privarla de su linfa vital» (68). Para Warburg, debe comprenderse la «necesidad biológica» de las imágenes, «como producto entre la religión y la práctica

19 Los especialistas suelen situar la «explicitación» del concepto de Pathosformel en este artículo de 1905, donde Warburg reconduce el motivo, tanático y erótico a la vez, de la muerte de Orfeo por manos de sus amantes, en un dibujo de Durero de 1494 y en su modelo -un grabado en cobre anónimo de Italia septentrional-, al lenguaje gestual patético del arte antiguo. Dice Warburg allí: «El típico lenguaje mimético patético del art antigo, tal como Grecia lo había elaborado para esta escena trágica, incide aquí determinando directamente el estilo». Inmediatamente después, enumerando una serie de obras muy diferentes que representan la «muerte de Orfeo», Warburg afirma que todas ellas «muestran [...] con tanta fuerza vital esta misma fórmula patética, arqueológicamente fiel (archäologisch getreue Pathosformel), inspirada en una representación de Orfeo o de Penteo» cfr. Warburg, La rinascita del paganesimo antico 195-96.

20 Se trata de "Sandro Botticelli Geburt der Venus und Frühling» en Warburg (La rinascita del paganesimo antico $4-22$ ). 
artística» (Agamben, «Aby Warburg e la scienza senza nome» 127) y es por ello que debe estudiarse la imagen fuera de los límites de la estética. De esta manera, Warburg ofrece a Agamben un modo de pensar la producción de imágenes más allá de la perspectiva muerta que representa la estética como disciplina abocada al ejercicio del gusto. Y lo hace restituyendo su relación con lo biológico, en la medida en que comprende, acaso de la mano de Nietzsche, por un lado, la obra de arte renacentista como una fuerza vital, como un "organismo dotado de energía vital», y por otro, la supervivencia -transmisión- en él de la polaridad entre ethos apolíneo y pathos dionisíaco inherente a la tragedia de la cultura. La obra de arte, desde esta mirada, no puede ser considerada como un objeto de conocimiento o de fruición desinteresada, sino que, como sugiere Didi-Huberman, Warburg nos da a entender que:

ante cada obra nos vemos concernidos, implicados en algo que no es exactamente una cosa sino más bien -y en este punto Warburg hablaba como Nietzsche- una fuerza vital que no podemos reducir a sus elementos objetivos (129).

En las numerosas páginas que Didi-Huberman dedica a la recepción warburguiana de Nietzsche y de Burckhardt, vemos construirse una interpretación del problema del Nachleben de las imágenes que enfatiza la segunda de las palabras que componen el concepto: Leben. La intención de Warburg, se nos dice, era la de comprender la «vida», la «fuerza» o "potencia» (Kraft, Macht) impersonal que sobrevive en las imágenes. Pero esta vida es la vida de una cultura, una vida que, aunque conserva plenamente su carácter natural -la emotividad primordial- es también una vida histórica, no natural (cfr. Didi-Huberman 279). De esta manera, el problema de la transmisión de lo antiguo que Warburg intenta reconstruir alejándose del concepto de imitación winckelmanniano, implica una idea de Lebensenergie, fuerza o reflujo que sobrevive en el arte. El Nachleben des Heidentums en el arte del Renacimiento es entonces la supervivencia, entendida como una vida continuada en este mundo, del carácter polar y exuberante de la vida cultural antigua: una belleza a la vez superficial y terrible, humana y animal, que combate sin reconciliación duradera dentro de la imagen. La humanidad cristiana, como ya lo había alertado Nietzsche, «estará atravesada por una energía pagana cuyas supervivencias fueron precisamente el objeto de toda la investigación de Warburg» (Didi-Huberman 137). Las fórmulas antiguas, reapropiadas y cambiadas, sobreviven en la memoria inconsciente, material, transmitida «en la carne y en la sangre», pues es ella misma la carne de las cosas, el material plástico del que están hechas las imágenes.

En su ensayo de 1975, Agamben reconduce esta idea de la memoria a un pensador que había influenciado profundamente la idea de Warburg, Richard Semon. En una cita que Agamben toma del libro de Gombrich sobre Warburg, se presenta el carácter no consciente que tiene la memoria para Semon, quien la entiende como «la cualidad que distingue al viviente de la materia inorgánica» y como capacidad de reaccionar frente a un evento a través de un período de tiempo, una manera de 
conservar y transmitir la energía desconocida en el mundo físico (Agamben, «Aby Warburg e la scienza senza nome»131).

Llegados a este punto podría sugerirse, como lo ha hecho recientemente Ludueña, que la ciencia de Warburg es una «ciencia de lo viviente en cuanto ser sensitivo» (19). La memoria warburguiana actúa a partir de polaridades psíquicas, experiencias emotivas fundamentales que sobreviven en las imágenes. Warburg se interesa primeramente por las emociones que las imágenes acumulan y desplazan, y por lo tanto su proyecto debe entenderse, sostiene Ludueña, como una "pathología ultrahistórica de la cual las imágenes son solamente signos exteriores» (19). Poniendo el énfasis en la supervivencia de las emociones que invaden al hombre desde fuera y a las que el hombre tiene acceso en su condición sensitiva (animal), Ludueña despoja al pensamiento warburguiano de toda posible edulcoración humanista. Pues, lejos de ser una ciencia de lo humano, como había creído ver el mismo Agamben en 1975, la ciencia de Warburg da cuenta de que:

aquello que distingue al hombre del resto de los vivientes es aquel proceso biológicohistórico conocido como hominización y que podría ser descrito como el acceso al control multipolar de las emociones cósmicas por parte del viviente hombre. Desde este punto de vista, el interés warburguiano por la antropogénesis está dado en la medida en que son las emociones las que fabrican lo humano, pero, justamente por ello, estas no tienen estricta necesidad de lo humano para subsistir en el mundo (19).

Esta cita nos arroja algo lejos de la perspectiva de Agamben que estamos considerando. En efecto, por estos años, la preocupación de Agamben todavía no está centrada en el proceso de hominización, ni su lectura de Warburg nos permite salir de la propuesta de una "ciencia general de lo humano", sin embargo, acaso sea posible comprender algunas de sus consideraciones posteriores a partir de este espacio a-subjetivo que son las emociones en la lectura ludueña de Warburg. En efecto, por mencionar un ejemplo del que no nos ocuparemos aquí, en «Genius» Agamben traza una idea de lo «impersonal» a partir de la consideración simondoniana de las emociones como "el umbral de toda individuación» (4). Si la prerrogativa del arte es la conservación y la transformación de esa energía fisiológica, es decir, de las emociones que son la experiencia de lo impersonal, acaso pueda entonces avanzarse con ella hacia la concepción de una forma de vida que, por un lado, exceda los límites de lo humano y, por el otro, de lo estrictamente biológico.

Otro género de vida, la supervivencia, se delinea en ese resto de vida que se mueve en la oscilación entre lo no totalmente vivo y lo no totalmente muerto: su forma corporal es la Pathosformel, que plantea una relación inédita entre forma y contenido. Como el Eros stilnovista, o como el Dionisos nietzscheano que inspiró los poemas agambenianos, esta vida (esta sobrevida) se presenta como un fenómeno dúplice, no dicotómico sino polar, siempre en la tensión entre lo extático y lo depresivo, entre violencias y latencias. 


\section{La vida histórica de la ninfa}

En «Aby Warburg e la scienza senza nome», Agamben había señalado como uno de los dos temas centrales en la investigación de Warburg, la cuestión de la «ninfa» $(137)^{21}$. En 2004 volverá sobre esa figura con una reflexión que nos devuelve al seno de sus preocupaciones en Stanze: la ninfa será, en efecto, el habitante puramente gestual, hecho de tiempo, de ese «reino de lo irreal» cuya cartografía aproximada y provisoria ha querido trazar en Stanze. Esta Pathosformel será extendida y tensada, estudiada e imaginada hasta convertirse en la cifra de toda Pathosformel, imagen de la imagen, en la que convergen los fantasmata de la teoría aristotélica de la memoria, las Vivian Girls de Darger, el tratado sobre los espíritus elementales de Paracelso, la «ninfa florentina» de Boccaccio y la aporética teoría de la imaginación «medial» de Averroes ${ }^{22}$. Así, en este artículo Agamben continúa el análisis warburguiano de las fórmulas patéticas independientemente de su «soporte material», trátese de pinturas, dibujos, videos, teorías filosóficas o locus poéticos. Al modo de la tabla 46 del Atlante Mnemosyne dedicada a esta figura -que recoge 26 fotos que van desde bajorrelieves del siglo viI, frescos de Botticelli o Ghirlandaio, tarjetas postales romanas, a una fotografía de una campesina tomada por Warburg ${ }^{23}$-, Agamben recorre diferentes manifestaciones del arte contemporáneo, composiciones poéticas, ideas estéticas sobre la danza o ideas

21 El otro tema es el del «revival astrológico» en el Renacimiento, tema del que se ocupará en Infanzia e Storia (15).

22 No me detendré aquí en estas figuras, pero vale la pena retener para lo que sigue algunas de las características que Agamben señala de la «ninfa dargeriana» y de la «ninfa» de Paracelso. Con respecto a la primera, Agamben describe el procedimiento compositivo de las ilustraciones que acompañan la novela de más de treinta mil páginas que fue encontrada en 1972 en el departamento en el que vivió Henry Darger, como caso extremo de una composición artística por Pathosformel. Su técnica consistía en recortar imágenes de niñas de álbumes de figuritas o de diarios para disponer de un repertorio formal y gestual que combinaba en sus paneles: "Como todo verdadero artista, [Darger] no quería simplemente construir la imagen de un cuerpo, sino un cuerpo para la imagen» (Agamben, «Nimphae» 57). In the Realms of the Unreal, tal es el nombre de la novela, es un intento pigmaliónico y genial de restituir las imágenes a la vida. Con respecto a la segunda, algo más adelante en el mismo artículo, Agamben refiere como antecedente de Warburg -con su habitual recurso de «descubrir» fuentes que han permanecido ocultas hasta el momento para los estudiosos- el tratado de Paracelso De nymphis, silphis, pygmeis et salamandris et caeteris spiritibus. Allí Paracelso restituye la doctrina bombastiana de los espíritus elementales, entre los cuales se encuentra la ninfa, ligada al agua. Estos espíritus pertenecen a un tipo de creación especial: tienen razón y habla -no son animales-, tienen cuerpo -no son espíritus-, pero no tienen alma -no son hombres-. Más que animales y menos que hombres, son criaturas híbridas de cuerpo y espíritu. Creados por Dios en los elementos mundanos son condenados sin culpa a una vida puramente animal. La especificidad de las ninfas, según Paracelso, consiste en que "pueden recibir un alma si se unen sexualmente con un hombre y generan un hijo [...] Condenadas de este modo a una incesante y amorosa búsqueda del hombre, las ninfas llevan sobre la tierra una existencia paralela [...] La historia de la ambigua relación entre los hombres y las ninfas -concluye Agamben-, es la historia de la difícil relación entre el hombre y sus imágenes» (63-4).

23 El atlas Mnemosyne está compuesto por una serie de tablas constituidas por el montaje fotográfico de reproducciones de obras de diversos tipos: gran parte de las imágenes corresponden a testimonios renacentistas (obras de arte, páginas de manuscritos, cartas de juego, etc.), pero también hay un repertorio arqueológico de la Antigüedad oriental, griega y romana y una serie de testimonios de la cultura del siglo xx (fotos de diarios, publicidades o estampillas) (Warburg, Atlas Mnemosyne 84-5). 
filosóficas, para bosquejar una vida «puramente histórica» situada exactamente en la zona incierta entre lo individual y lo común, la sensación y el pensamiento.

Tal como refería Agamben en el artículo de 1975, Warburg se ocupa de esta «figura femenina en movimiento, con las ropas agitadas», que aparece como tópico en los artistas del Quattrocento y que es explicada como un Nachleben der Antike, ya en su tesis sobre el Nacimiento de Venus y La primavera de Sandro Botticelli. Esta muchacha joven con sus cabellos, ropas y miembros en movimiento, es una figura recurrente en las representaciones literarias, pictóricas y ceremoniales de la época. Se trata de una Pathosformel clásica, conservada en las paredes de los sarcófagos antiguos, con la que los artistas del Quattrocento evocan la vitalidad pagana, latente en textos e imágenes antiguos pero olvidados en los siglos de cristianismo medieval. En su aparición se revela «la polaridad dionisíaca del arte clásico que, tras los pasos de Nietzsche, pero tal vez por primera vez en la esfera de la historia del arte [...], Warburg afirmó resueltamente» (Agamben, La potenza del pensiero 138), y con ella, un profundo conflicto espiritual en la cultura del Renacimiento, que se corresponde con la trágica esquizofrenia de la cultura occidental en su conjunto.

Tras haber asumido la inviabilidad del proyecto de una ciencia general de lo humano que él había creído entrever en la obra de Warburg, y tras haber replanteado su objeto de estudio como el «problema del estatuto de la imagen», reenviándolo a la investigación benjaminiana sobre la imagen dialéctica, en la «Apostilla» de 1983 al artículo de 1975, Agamben culmina evocando nuevamente la figura de la ninfa:

La «ninfa» warburguiana no es, a esta altura, ni un objeto externo ni un ente intrapsíquico, sino la figura más límpida del propio sujeto histórico. Así como el atlante Mnemosyne [...] no es, para la conciencia del estudioso, un repertorio iconográfico, sino algo así como un espejo de Narciso (146, la traducción es mía).

Warburg comprendió, señala nuestro autor, que se trataba de «aferrar la pura materia histórica». La ninfa es una supervivencia encarnada, una imagen cargada de tiempo, un «fósil en movimiento» que desafía al tiempo cronológico (Didi-Huberman 182). Y el atlas es un espejo en el que se refleja esa imagen que amamos (la ninfa), pero es, a la vez, un mapa que debe orientarnos entre los reflejos para que no se vuelvan espectros esclavizantes.

El trabajo sobre la Pathosformel warburguiana que se emprende en «Nimphae», cuando Agamben ha escrito ya varios tomos de "la saga homo sacer» ${ }^{24}$, está atravesado, como el tercero de los ensayos de Stanze, por la pregunta acerca del amor por la imagen, y se cierra con una consideración de la imaginación que intenta dar cuenta de una dimensión medial, histórica y colectiva en la oscilación entre el singolo nomo y una multitudo. Este último será un tema recurrente a partir de los años noventa en la filosofía de Agamben, pero ha de notarse que ya en «La parola

24 En una entrevista con R. Andreotti y F. De Melis, Agamben señala: «He vuelto sobre Warburg luego de muchos años: tenía necesidad de ello, creo, después de esta inversión en los problemas de filosofía política» (Andreotti-De Meli 2, la traducción es mía). 
e il fantasma» Agamben atribuía a Averroes un lugar central en el desarrollo de la fantasmología que culmina en la teoría del amor stilnovista, que de algún modo adelantaba algunas de sus consideraciones posteriores. Luego de haber recorrido los antecedentes antiguos, es decir, la teoría platónica de la imagen interior (fantasmata) que dibuja la fantasía (Filebo y Teetetos) y, fundamentalmente, la teoría aristotélica que conecta explícitamente la fantasía con la memoria (De anima y De memoria et reminiscentia), Agamben analiza el modo en que el pensamiento medieval hizo del fantasma el «lugar de una extrema experiencia del alma» (Stanze 90) y lo conectó con las doctrinas médicas (es el caso específico de Avicena). Pero será Averroes, antecedente fundamental de Dante y de Cavalcanti, el responsable de una doctrina polémica pero decisiva acerca de un procedimiento cognoscitivo no representativo, subjetivo o psicológico, sino «especulativo». El conocimiento es, para Averroes, un reflejarse de fantasmas como en un espejo y la imaginación es la copulatio entre el fantasma y el intelecto único y separado. La experiencia cognoscitiva averroísta es la de Narciso frente al espejo: un amor en la exterioridad, no en el aislamiento de la "profundidad del alma». Como señala Coccia, «los espejos proporcionan el modelo y el paradigma a través del cual poder definir qué ocurre en todo conocimiento. En el espejo, en efecto, cada cosa consiste en la simple posibilidad de ser conocida» (230). Aunque Agamben aquí no se detiene en la lectura averroísta del intelecto posible, indica la importancia que tiene para la teoría del fantasma la concepción de la inteligencia como algo supraindividual a lo cual se unen los individuos en el acto de intelección, a través, justamente, de sus fantasmas:

Situada en el vértice del alma individual, en el límite entre individual y universal, corpóreo e incorpóreo, [la imagen] es la escoria estragada de cenizas que la combustión de la existencia individual abandona en el umbral ileso e intransitable de lo Separado y lo Eterno (Agamben, Stanze 102, la taducción es mía).

En la última sección de «Nimphae», Agamben escribirá esta misma frase agregando a la lista la dupla sensación / pensamiento, cambiando «imagen», por la «imaginación» (pensada en el momento de su umbral crítico y de su formulación más aporética, es decir, con Averroes), cambiando «universal» por «común» y abandonando las mayúsculas en «separado" y «eterno» (lo cual, en un filósofo que ha meditado sobre los más pequeños detalles, y que ha comenzado a pensar lo común más allá de la trampa dicotómica individual / universal, no deja de resultar sugerente). Interesado en el aspecto inhumano y común del pensamiento, en su aspecto intermitente y ausente más que en su carácter «divino», Agamben sostiene que la facultad que define lo humano, la imaginación, es precisamente aquella que arroja al hombre a un espacio «en el que no pensamos todavía, en el que el pensamiento deviene posible solo a través de una imposibilidad de pensar» (Agamben, «Nimphae» 66). Las imágenes constituyen, de este modo, la consistencia última de lo humano a la vez que el único medio de salvación, pero son «el lugar de su incesante faltarse a sí mismo» (66). 
Es en esta huella averroísta donde Agamben quiere situar el proyecto que ocupaba a Warburg al final de su vida, la colección de imágenes recogidas en el atlas que lleva el nombre de la madre de todas las Musas, la memoria. La «ninfa», como cifra de toda Pathosformel, traslada esta ambigüedad de la imagen a un plano colectivo e histórico, como lo hizo antes Dante en De monarchia al interpretar la definición de lo humano como una "posibilidad de pensar» en términos colectivos: solo una multitudo en el tiempo y en el espacio puede poner en acto -nunca plenamente, por lo demás- la posibilidad (potencia) del pensamiento ${ }^{25}$. El interés de Agamben aquí reside en mostrar no ya la mediación entre corpóreo e incorpóreo (lo cual nos mantendría acaso en un plano fisiológico, biológico) sino la que existe entre lo individual y lo colectivo, mediación que se da en la historia -en la supervivencia de las imágenes- que cifra la posibilidad de encontrarse o perderse en el pasaje de las imágenes de generación tras generación.

\section{Espejo y espectáculo}

Vivir como hombres significa amar las imágenes, vivir entre fantasmas tendidos hacia el abismo de lo inhumano. En el curso de la tradición histórica, no obstante, las imágenes se han cristalizado, se han transformado en espectros que esclavizan a los hombres. El comercio con las ninfas, que necesitan unirse a los hombres para adquirir un alma y sobrevivir, implica un riesgo mortal para los hombres ya que pueden quedar atrapados en ello. Las imágenes atan al hombre a un destino, le dicen quién es y circunscriben su «esencia», aunque solo sean «el resto, la huella de lo que los hombres que nos precedieron esperaron y desearon, temido y removido» (Agamben, «Nimphae» 67). Por ello los hombres necesitan estar en condiciones de suspender el «dinamograma cargado de tiempo» e invertir su carga, transformar el destino en fortuna. Para ponerlo en otros términos, podríamos decir que la historia ha devenido metafísica, hemos puesto completamente fuera, y en el lugar del fundamento, aquello que es un producto híbrido entre lo individual y lo impersonal: la nuestra es una "historia de fantasmas para adultos» (como decía Warburg de su Atlas), pues estamos sometidos a la tiranía de nuestras imaginaciones.

La especulación, el espejo en el que contemplábamos embelesados la imagen, se ha transformado en espectáculo. Agamben se encontró, en algún lugar entre Stanze y «Nimphae», con Guy Debord. En 1967 Debord había diagnosticado la transformación de la política y de toda la vida social en «una fantasmagoría espectacular»; el espectáculo, sentenciaba, «no es un conjunto de imágenes sino una relación social entre las personas mediatizada por las imágenes», el núcleo irreal de la sociedad real

25 No podría aquí abordar la cuestión de la interpretación dantesca de Averroes y sobre el problema del intelecto posible que Agamben aborda en numerosos textos, mi intención es dejar esbozada la idea de un desplazamiento "político" de su filosofía que implica esta nueva lectura de Warburg en el contexto del averroísmo, así como la posibilidad de pensar el Nachleben como una "vida histórica» colectiva. 
(38). La imagen espectacular «es la afirmación de la apariencia y la afirmación de toda vida humana, o sea social, como simple apariencia», pero en eso se revela como "la negación visible de la vida, como una negación de la vida que se ha tornado visible» (40). Todo lo vivido se transforma en una representación. Por ello, si en las imágenes al hombre se le juega su carácter de humano, como señala Agamben, el espectáculo es la expropiación de la sociabilidad humana, pues el hombre queda encerrado en una eterna separación donde el mundo real se transformó en una imagen y las imágenes se han vuelto reales (Agamben, "Violenza e speranza nell'ultimo spettacolo»9).

Agamben piensa el último proyecto warburguiano como un modo crítico de hacerse cargo de la necesidad de acceder a otra dimensión de la memoria en la que el hombre no quede atrapado en la esquizofrenia de la imaginación. Atlante sosteniendo el cosmos acaso sea precisamente la figura de quien puede asumir el carácter aporético, intermedio de su imaginación entre la sensación y el pensamiento y de su memoria entre el recuerdo y el olvido. En una carta escrita antes de morir, Warburg reformula el proyecto de su atlas como una «teoría de la función de la memoria por imágenes [Theorie des Funktion des menschlinchen Bildgedächtnisses]» (Agamben, «Nimphae» 67), y en ello ve Agamben el intento por trazar un mapa para que el hombre pueda dominar la memoria, para que pueda acceder a una zona más allá de la escisión, en la revocación imaginaria de todas las imágenes.

La tradición de las imágenes es también su traición, la tentativa de liberarse de ellas, como indica aquella línea de pensamiento iniciada con Nietzsche a la que Warburg no fue indiferente ${ }^{26}$. En la Segunda consideración intempestiva, Nietzsche denunciaba una hipertrofia de la historia que la lleva a la acumulación indiferente del pasado, a una pacificación de todo lo sucedido e instaba a dirigir el pensamiento contra sí mismo y encontrar otros modos posibles para el hacer y la comunicación ${ }^{27}$. En la metafísica de la presencia las imágenes se acumulan y conservan hasta digitar el destino de la humanidad: las ninfas necesitan de un sujeto, lo construyen y lo sujetan en su separación. Pero otra relación con el pasado es posible, una relación en la que el comercio con las ninfas sea siempre un proceso de subjetivación y desubjetivación provisorio, asumido en el riesgo de su infundamentación y de su imposible identificación. En las Pathosformel, la memoria es memoria de una huella que sobrevive -si se me permite-

26 Tengo aquí en cuenta las consideraciones de M. B. Cragnolini, quien ha ubicado a Agamben en esta línea nietzscheano-derrideana que concibe la memoria no como «recuerdo interiorizante que quiere «conservar»» sino como la "posibilidad siempre despresentificada, habitada por la ausencia» (3-9).

27 Retomando a Leopardi, Nietzsche comienza este libro estableciendo una diferencia entre el animal que vive felizmente en el presente y el hombre hundido en el paso del tiempo, y propone un conocimiento de la fuerza plástica, como "poder de transformar y asimilar lo pasado, de regenerar las formas destruidas», que permita establecer «los límites en los que el pasado ha de olvidarse para no convertirse en sepulturero del presente». Se trata, entonces, para Nietzsche, no de volver a una naturalidad deshistorizada, sino de comprender la necesaria oscilación entre lo ahistórico y lo histórico para "la salud de un individuo, de un pueblo o de una cultura» (Nietzsche, Sobre la utilidad y los inconvenientes de los estudios históricos para la vida 43 y 45). En un intento por describir la arqueología filosófica melandriana y foucaultiana en la que busca inscribirse, Agamben retomará la idea de "historia crítica» nietzscheana a la que describirá como: «aquella historia que critica y destruye el pasado, para volver posible la vida» (Agamben, Signatura Rerum 98, la traducción es mía). 
en su «supervivilidad»: sobrevive no como un contenido, sino como una mera forma, como una mera posibilidad de sobrevivir (como «transmisibilidad», para decirlo con el término benjaminiano habitual en Agamben desde su primer libro). De esa memoria no hay archivo posible, pues no está hecha de recuerdos sino de olvidos, o mejor: de recuerdos que no recuerdan nada, que, según afirma el poeta, son los recuerdos más fuertes ${ }^{28}$. La memoria humana es elegíaca, se nos dice en «Idea dell'immemorabile», su contenido es el lamento por una ausencia. No es lo vivido lo que recordamos, en la memoria añoramos lo que nunca sucedió. La vida, por esto, es invulnerable a la memoria, pues «[1]o inmemorable, que se precipita de memoria en memoria, sin salir nunca al recuerdo, es propiamente inolvidable» (Agamben, Idea della prosa 48).

Acaso la historiografía warburguiana haya logrado acceder a esa «otra dimensión de la memoria» que ya no puede conservarse en el archivo (sea este de palabras o de imágenes), pues es lo Inolvidable mismo. Y acaso haya logrado mantenerse en el umbral inmaterial que divide lo Memorable y lo Inolvidable, sin confundirlos. Porque, advierte Agamben en un breve escrito dedicado al Denkmal für die ermordeten Juden Europas de Eisenman, «es esencial que aquellos no se confundan, que la mala conciencia que solo quiere olvidar no cubra con la masa de los recuerdos aquello que debe permanecer (restare) inolvidable» (Agamben, «Le due memorie» 62). Lo Inolvidable resiste e interrumpe, discontinuándola, la ficción de la memoria social.

Desde esta perspectiva, el atlas warburguiano no es un repertorio inmóvil de imágenes que archiva significaciones, que determina y garantiza la imperturbabilidad de lo Memorable; cada imagen en él contenida no tiene una realidad autónoma, sino que se funde en esa especie de «representación en movimiento virtual de los gestos de la humanidad occidental, desde la Grecia clásica al fascismo», que es el atlas (Agamben, Mezzi senza fine 49). Warburg, así, ha transformado la imagen en gesto, exorcizando su poder paralizante y su tendencia a cristalizarse en destino, dinamizándola. El gesto, eso de lo que están hechos el cine y la danza, «es la exhibición de una medialidad, el hacer visible un medio como tal» (52): comunicación de una comunicabilidad.

Así se entiende que el atlas sea la tentativa de mantenerse en la pura medialidad de la imaginación, donde las imágenes a la vez se refugian y se despiden. «El título Mnemosyne, nombra, en este sentido, lo sin imagen, que es la despedida -y el refugio- de todas las imágenes» (Agamben, «Nimphae» 67).

\section{A MODO DE CONCLUSIÓN}

El contacto con el pensamiento de Warburg ha sido, como he intentado señalar, determinante en la formación de Agamben. Acaso sea viable afirmar, luego de este recorrido, que la fascinación por el paganismo latente en su obra poética juvenil de cuño nietzscheano y en el análisis de Artaud y Klossowski en sus primeros artículos,

28 Se trata de una frase de Dino Campana, «este recuerdo que no recuerda nada es el más fuerte», que Agamben cita al final del texto que dedica al análisis del eterno retorno y la voluntad de poder nietzscheanos (Agamben, La potenza del pensiero 343). 
sobrevive mutada, transformada en un interés por la tradición medieval y por esa zona de indeterminación de una pura medialidad sin fin en la que luego intentará emplazar, frente a la biopolítica, una «política que viene».

El proyecto de una ciencia general de lo humano, tal como se planteaba en Stanze, o el proyecto de una «antropología histórica de lo humano», como quiso ver en la obra de Warburg, deberá ser abandonado, tal como el propio Agamben volverá a señalar muchos años más tarde ${ }^{29}$. Si este proyecto fracasó, acaso haya sido porque aquella ciencia sin nombre y sin objeto, que localiza un tercer espacio entre el sujeto y el objeto, lejos de asumir la escisión entre lo humano y lo no humano como su «objeto» propio (al modo metafísico tradicional), la desplaza, al menos tímidamente, hacia la pregunta por lo viviente. En los libros siguientes la pregunta que guíe las investigaciones será ¿qué significa vivir como humano?, o, lo que es lo mismo, ¿qué significa tener lenguaje? Pero aquí se nos habrán dado ya algunas pistas, provenientes todas ellas de si filosofía del arte, acerca de la revocabilidad del sujeto y acerca de la posibilidad de pensar una vida -sobrevida-, que sea una amalgama de lo biológico y lo histórico.

\section{REFERENCIAS}

Agamben, Giorgio. "Aby Warburg e la scienza del nome». La potenza del pensiero. Saggi e conferenze. 1975. Vicenza: Neri Pozza, 2005. 123-46. Medio impreso.

---. «Decadenza». Rivista Futuro 6 (1964). 28-32. Medio impreso.

---. «Gusto». Enciclopedia. Vol. 6. Ed. Ruggero Romano. Torino: Einaudi, 1979. Medio impreso.

---. «Filologia e linguistica». La potenza del pensiero. Saggi e conferenze. 1990. Vicenza: Neri Pozza, 2005. 57-66. Medio impreso.

---. Idea della prosa. Macerata: Quodlibet, 2002. Medio impreso.

---. Il regno e la gloria, Per una genealogia teologica dell'economia e del governo, Homo sacer II, 2.Vincenza: Neri Pozza, 2007. Medio impreso.

---. Il sacramento del linguaggio, Archeologia del giuramento, Homo Sacer II, 3. RomaBari: Laterza, 2008. Medio impreso.

---. Infanzia e storia. Distruzione dell'esperienza e origine della storia. Torino: Einaudi, 2001. Medio impreso.

---. Il linguaggio e la morte, Un seminario sul luogo della negatività.Torino: Einaudi, 2008. Medio impreso.

---. «La 121 aiornata di Sodoma e Gomorra». Tempo presente 3-4. Vol. 11 (1966). 59-70. Medio impreso.

---. «La parola e il sapere». Aut aut 179-180 (1980). Firenze: La Nuova Italia. 155-166. Medio impreso.

29 Cfr. por ejemplo «Filosofia e lingüística»(1990) en La potenza del pensiero, 60 o el comienzo de $I l$ sacramento del linguaggio, Archeologia del linguaggip. Homo sacer II, 3, 4. 
---. «Le due memorie». Shoah, Percorsi della memoria. Ed. Clemens Carl Härle. Napoli: Cronopio, 2006. 61-3. Medio impreso.

---. «L'io, l'occhio, la voce». La potenza del pensiero. Saggi e conferenze. 1980. Vicenza: Neri Pozza, 2005. 91-106. Medio impreso.

---. L'uomo senza contenuto. Macerata: Quodlibet, 1994. Medio impreso.

---. Mezzi senza fine, Note sulla politica. Torino: Bollati Boringhieri, 1996. Medio impreso.

---. «Nimphae». Aut Aut 321-322: Aby Warburg. La dialettica dell'immagine (2004).

53-67. Medio impreso.

---. Profanazioni. Roma: Nottetempo, 2005. Medio impreso.

---. Quel che resta di Auschwitz, L'archivio e il testimone, Homo sacer III, Torino: Bollati Boringhieri, 1998. Medio impreso.

---. Signatura Rerum. Sul metodo. Torino: Bollati Boringhieri, 2008. Medio impreso.

---. Stanze. La parola e il fantasma nella cultura occidentale, Torino: Einaudi, 1979. Medio impreso.

---. «Violenza e speranza nell'ultimo spettacolo: Dal maggio francese a piazza Tian An Men». Il manifesto (1989). 1-2. Medio impreso.

Andreotti, Roberto y De Melis, Federico. «Le costellazioni di Agamben». Alias 35 (2006). 1-5. Medio impreso.

Bartolini, Paolo. «The Stanza of the Self: on Agamben's Potentiality». Contretemps, An Online Journal Of Philosophy 5 (2004). 8-15. Medio impreso.

Burucúa, Gastón. Historia, arte, cultura, De Aby Warburg a Carlo Ginsburg. Buenos Aires: Fondo de Cultura Económica, 2007. Medio impreso.

Coccia, Emmanuelle. Filosofía de la imaginación, Averroes y el averroísmo. Trad. María Teresa D'Meza. Buenos Aires: Adriana Hidalgo, 2007. Medio impreso.

Cragnolini, Mónica. «La memoria en G. Agamben: entre Mnemosyne y la potencialidad». Espacios de crítica y producción (2005). 3-9. Medio impreso.

Debord, Guy. La sociedad del espectáculo. Trad. José Luis Pardo. Valencia: Pre-textos, 2007. Medio impreso.

De la Durantaye, Lealand. Giorgio Agamben, a Critical Introduction. Stanford/ California: Stanford University Press, 2009. Medio impreso.

Didi-Huberman, Georges. La imagen superviviente, Historia del arte y tiempo de los fantasmas según Aby Warburg. Trad. Juan Calatrava. Madrid: Abada, 2009. Medio impreso.

Foucault, Michel. Dits et Ecrits. Vol. II. París: Gallimard, 1994. Medio impreso.

Ludueña, Fabián. «Eternidad, espectralidad, ontología: hacia una estética trans-objetual». Pequeño manual de inestética. Ed. Alain Badiou. Trad. Guadalupe Molina, Lucía Vogelfang, Jorge Caputo y Marcelo Burello. Buenos Aires: Prometeo, 2009. 9-39. Medio impreso.

Nietzsche, Friedrich. La genealogía de la moral. Trad. Andrés Sánchez Pascual. Madrid: Alianza, 1994. Medio impreso. 
Nietzsche, Friedrich. Sobre la utilidad y el perjuicio de la historia para la vida, II Intempestiva. Trad. Germán Cano. Madrid: Biblioteca Nueva, 1999. Medio impreso.

Ortega y Gasset, José. La deshumanización del arte y otros ensayos de estética. Barcelona: Óptima, 1998. Medio impreso.

Parry, Milman. «Studies in the Epic Technique of Oral Verse-Making, I. Homer and Homeric Style». The making of Homeric Verse: the collected papers of Milman Parry. New York-Oxford: Oxford University Press, 1987 .266-324. Medio impreso.

Sofri, Andrea. «Un'idea di Giorgio Agamben». Reporter, 9 y 10 de noviembre de 1985. 32-3. Medio impreso.

Tarrizo, Davide. La vita, un'invenzione recente. Roma-Bari: Laterza, 2010. Medio impreso.

Valéry, Paul. El discurso del árbol. Trad. Rodolfo Alonso. Córdoba: Ediciones del copista, 2004. Medio impreso.

Warburg, Aby. Atlas Mnemosyne. Trad. Joaquín Chamorro Mielke. Madrid: Akal, 2010. 193-200. Medio impreso.

Warburg, Aby. «Dürer e l'antichità italiana». La rinascita del paganesimo antico. La rinascita del paganesimo antico. Contributi alla storia della cultura. Trad. it. Emma Cantimori. Firenze: La nuova Italia, 1966. Medio impreso.

Watkin, Wiliam. The literary Agamben. Adventures in logopoiesis, London-New York: Continuum, 2010. Medio impreso.

Wind, Edgar. «El concepto de Kulturwissenschaft en Warburg». La elocuencia de los símbolos, Estudios sobre arte humanista. Trad. Luis Millán. Madrid: Alianza, 1993. Medio impreso. 